\title{
Vasculitis in a cocaine user
}

\author{
Daniele Massera, Marcus Bachhuber, Liang Shen, Ameet Karambelkar
}

Division of General Internal Medicine, Department of Medicine, Montefiore Medical Center/Albert Einstein College of Medicine, Bronx, New York, USA

Correspondence to Dr Marcus Bachhuber, marcus.bachhuber@gmail.com

\section{DESCRIPTION}

A 45-year-old woman was admitted for a painful purpuric rash on her cheeks, ears and legs, which began after a 3-day period of heavy crack cocaine use. She reported a similar rash 3 years ago and a skin biopsy at that time revealed thrombi in the small blood vessels. However, serological testing was not consistent with any specific known diagnosis and she was discharged when her rash improved.

On physical examination, retiform purpuric lesions were seen across both cheeks (figure 1), with prominent lesions on the lobes and helices of both ears (figure 2), and across both legs. Laboratory testing revealed leukopaenia (3 400 cells $/ \mu \mathrm{l}$ ) with a borderline low granulocyte count (1500 cells $/ \mu \mathrm{l})$, positive antimyeloperoxidase antineutrophil cytoplasmic antibodies by ELISA $(1.3 \mathrm{U}$, normal $<1.0 \mathrm{U})$, a low C4 complement component (12 mg/dl, normal 16-56 mg/dl) and the presence of a lupus anticoagulant. Given the characteristic clinical and laboratory findings, cutaneous vasculitis associated with levamisole from adulterated cocaine was diagnosed.

Levamisole is an immunomodulatory agent but its medical use in humans was discontinued due to adverse effects including leukopaenia, agranulocytosis and a characteristic cutaneous small-vessel vasculitis with autoantibodies. For reasons largely unknown, it has emerged as a common cutting agent for cocaine, ${ }^{1}$ leading to similar syndromes among cocaine users. ${ }^{23}$ As the proportion of cocaine adulterated with levamisole appears to be increasing, ${ }^{1}$ clinicians should suspect levamisole-associated vasculitis in a

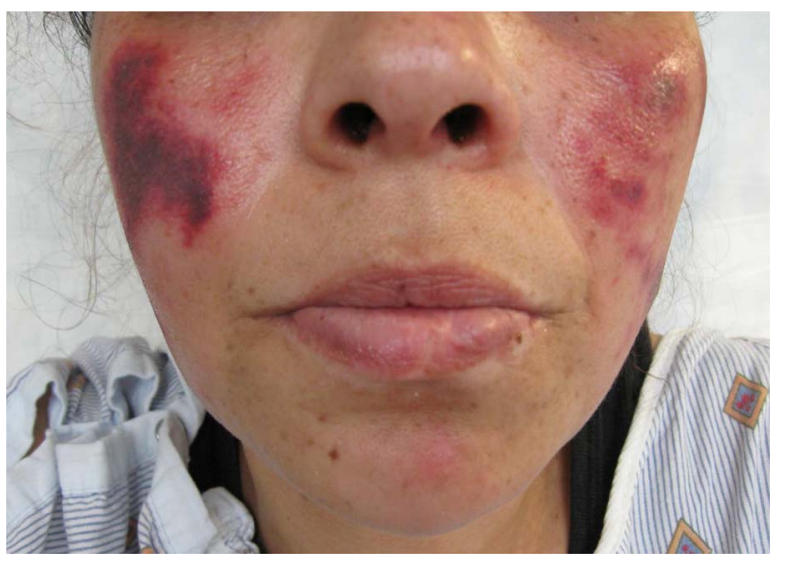

Figure 1 Characteristic retiform purpuric lesions on both cheeks in levamisole-associated vasculitis.

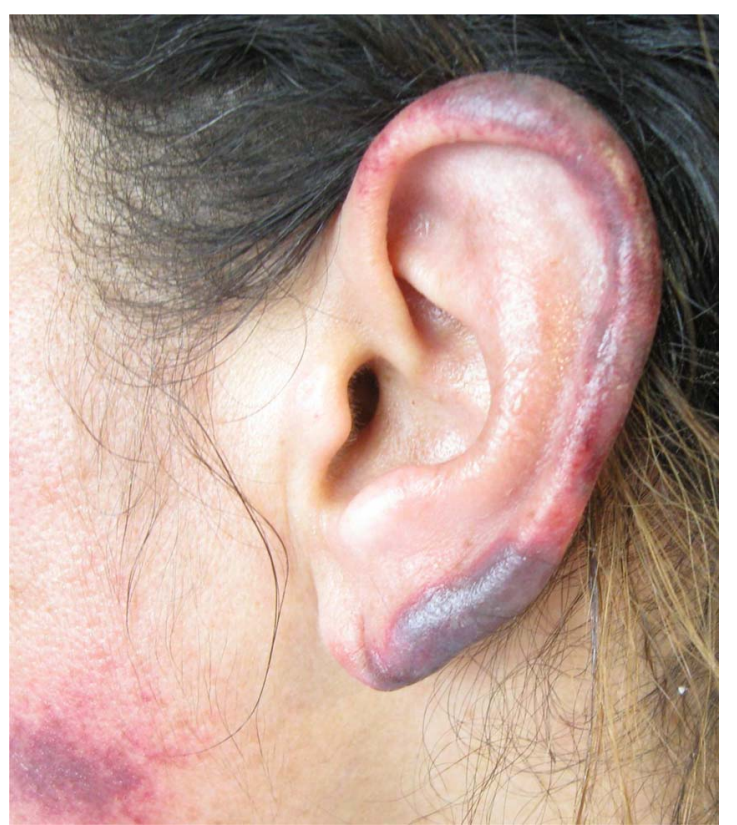

Figure 2 Involvement of the helices and pinna is typical in patients with levamisole-associated vasculitis.

patient with a history of cocaine use, characteristic lesions, leukopaenia or agranulocytosis, and a pattern of autoantibodies unusual for other vasculitides.

\section{Learning points}

- Levamisole is an immunomodulatory agent associated with a characteristic retiform purpuric rash, leukopaenia and agranulocytosis, as well as autoantibodies, including antineutrophil cytoplasmic antibodies, antinuclear antibodies and antiphospholipid antibodies in a pattern unusual for other vasculitides.

- It is increasingly found as an adulterant of street cocaine for reasons largely unknown.

- Case series have reported successful therapy with topical emollients and corticosteroids as well as systemic corticosteroids and immunosuppressants such as cyclosporine, but optimal treatment is unknown. 


\section{BMJ Case Reports}

\section{REFERENCES}

1. Chang A, Osterloh J, Thomas J. Levamisole: a dangerous new cocaine adulterant. Clin Pharmacol Ther 2010;88:408-11.

2. Gulati S, Donato AA. Lupus anticoagulant and ANCA associated thrombotic vasculopathy due to cocaine contaminated with levamisole: a case report and review of the literature. J Thromb Thrombolysis 2012;34:7-10.

3. Gross RL, Brucker J, Bahce-Altuntas A, et al. A novel cutaneous vasculitis syndrome induced by levamisole-contaminated cocaine. Clin Rheumatol 2011;30:1385-92.

Copyright 2012 BMJ Publishing Group. All rights reserved. For permission to reuse any of this content visit http://group.bmj.com/group/rights-licensing/permissions.

BMJ Case Report Fellows may re-use this article for personal use and teaching without any further permission.

Please cite this article as follows (you will need to access the article online to obtain the date of publication).

Massera D, Bachhuber M, Shen L, Karambelkar A. Vasculitis in a cocaine user. BMJ Case Reports 2012;10.1136/bcr-2012-007379, Published XXX

Become a Fellow of BMJ Case Reports today and you can:

- Submit as many cases as you like

- Enjoy fast sympathetic peer review and rapid publication of accepted articles

- Access all the published articles

- Re-use any of the published material for personal use and teaching without further permission

For information on Institutional Fellowships contact consortiasales@bmjgroup.com

Visit casereports.bmj.com for more articles like this and to become a Fellow 